\title{
Development of a protein binding assay for teleost insulin-like growth Factor (IGF)-like: relationships between growth hormone (GH) and IGF-like in the blood of rainbow trout (Oncorhynchus mykiss)
}

\author{
Ping-De Niu, Jaime Perez-Sanchez* and Pierre-Yves Le Bail \\ Laboratoire de Physiologie des Poissons, INRA, Campus de Beaulieu, 35042 Rennes France; * Instituto \\ de Acuicultura de Torre de la Sal (CSIC), Ribera de Cabanes, 12595 Torre de Sal, Castellon, Spain
}

Keywords: plasma, IGF, GH, salmonid, fish.

\section{Résume}

Un dosage des somatomédines (IGF) plasmatiques de téléostéens a été mise au point, en utilisant une protéine du sérum de truite qui lie spécifiquement les IGF humains (Niu and Le Bail 1993). Pour éliminer les risques d'interférence dues aux protéines de liaison (IGF-BP), l'activité IGF des différents échantillons a été extraite à l'aide de SP Sephadex C-25 en condition acide. La contamination en IGF-BP de ces extraits est estimée à $5 \%$ par dosage de la liaison et n'est pas détectable en western ligand blot.

L'IGF-I humain a été utilisée comme standard et comme traceur. La sensibilité du dosage est de 0.15-0.40 $\mathrm{ng} / \mathrm{ml}$ (ED90) et l'ED50 varie entre 1 et $3 \mathrm{ng} / \mathrm{ml}$. L'IGF-II humain est reconnue partiellement mais aucune réaction croisée n'est observée avec de l'insuline de différentes espèces ni avec les autres hormones testées. Les courbes d'inhibition obtenues avec les sera de mammifères et de téléostéens sont parallèles à la courbe standard. Ces résultats montrent que le dosage par protéine de liaison est capable de quantifier une activité de type IGF dans le sérum des téléostéen, et que le site de liaison des IGF est resté bien conservé au cours de l'évolution des vertébrés.

En utilisant ce dosage, nous avons mesuré l'activité IGF et les niveaux d'hormone de croissance (GH) dans des plasmas de jeunes truites arc-en-ciel abattues toutes les heures et demie durant $24 \mathrm{~h}$. Les profils nycthéméraux des deux hormones, qui sont de type pulsatile, apparaissent similaires. Une corrélation significative est observée entre les niveaux de GH et les activités IGF circulant une heure et demie plus tard. Des observations analogues ont été faites chez des truites adultes cathétérisées. Cependant, les niveaux plasmatiques de GH sont très différents d'un animal à l'autre, alors que les variations de l'activité IGF sont moins prononcées. Dans une troisième expérience, des truites ont été réparties en trois groupes: un groupe contrôle, un groupe traité avec de la GH bovine et un groupe soumis à un jeûne prolongé. Chez les animaux à jeun, les niveaux de GH augmentent alors que les activités IGF diminuent. Chez les animaux injectés avec de la GH, les activités IGF sont significativement plus élevées que chez les animaux témoins. Ces résultats suggèrent que, comme chez les mammifères, la sécrétion des IGF plasmatiques est contrôlée par les niveaux circulants de GH et que les variations de la réceptivité tissulaire à la GH dépendent de l'état nutritionnel des animaux. 


\begin{abstract}
Using rainbow trout plasma protein (IGF-BP) which specifically binds human insulin-like growth factor (IGF) (Niu and Le Bail 1993), we have developed an assay to measure plasma IGF-like levels in different teleost species. Before the assay and to prevent interference by IGF-BP, IGF-like was extracted from all samples, using SP Sephadex C-25 in acidic conditions. After this treatment, contamination of the IGF fraction by IGF-BP which was estimated by binding assay, was approximately $5 \%$, and was not detectable by western ligand blot.

Human IGF-I was used as standard and labelled hormone. Sensitivity of the assay was $0.15-0.40 \mathrm{ng} / \mathrm{ml}$ (ED90) and ED50 was $1-3 \mathrm{ng} / \mathrm{ml}$. hIGF-II crossreaction was partial and no significant displacement was observed with Insulin from different species or with other hormones. Inhibition curves were obtained with plasma IGF fractions (but not with tissue extracts) from teleost and mammals and are parallel to the standard curve. These results suggest that the protein binding assay can quantify an IGF-like factor in the plasma of teleost and that the binding sites of IGF are well conserved during vertebrate evolution.

Using this IGF binding assay, IGF-like was measured in parallel with growth hormone (GH) in plasma from young rainbow trout killed every $1.5 \mathrm{~h}$ throughout one day. The daily profiles for both hormones, which appear pulsatile, are similar. A significant correlation was observed between GH levels and IGF-like levels with a $1.5 \mathrm{~h}$ delay. Analogous observations were obtained in individual catheterized adult rainbow trout. Although plasma GH levels differ greatly between fish, less variability is found with IGF-like. In a third experiment, rainbow trout were starved or submitted to bovine GH treatment for four weeks. Starved fish, in which plasma GH levels increased, had plasma IGF-like level significantly lower than in fed fish. In bGH injected fish, plasma IGF-like level was significantly higher than in non-injected fish. These results suggest that, as in mammals, IGF-like secretion depends on plasma GH level and could be modulated by the nutritional status of fish.
\end{abstract}

\section{Introduction}

In teleosts, exogenous growth hormone $(\mathrm{GH})$ administration can stimulate additional growth under many conditions in intact animals, suggesting that $\mathrm{GH}$ is one of the most important factors which controls body growth. Compared to mammals and birds, teleosts seem to be "GH deficient". However, even within salmonids, the response to $\mathrm{GH}$ treatment using extraphysiological doses, is very heterogeneous and may vary with species, strain, environment factors and physiological state (Le Bail et al. 1993). In these experiments, differences of GH blood levels cannot be invoked to explain the variability of the growth response, suggesting that other regulations are involved in the control of growth.

In salmonids, $\mathrm{GH}$ receptors are present in various tissues (Gray 1990; Yao et al. 1991; PérezSanchez et al. 1991; Le Gac et al. 1992). Their number are modulated by stunting (Fryer and Bern
1979; Gray et al. 1990), salinity (Sakamoto and Hirano 1991), GH plasma levels, temperature or starvation (Pérez-Sanchez et al. 1991; Yao and Le Bail, unpublished data). However, GH receptors may not the only element involved in the receptivity of target tissues to GH. In mammals, the liver resistance to $\mathrm{GH}$ induced by some nutritional deficiencies may occur without modification to the number of affinity of liver GH receptors (Maiter $e t$ al. 1988; Thissen et al. 1990). To study the regulation of GH receptivity of a peripheral tissue such as liver, it is necessary to take into account factors or effects which are under the control of GH in this tissue. Among the different functions of the liver known in mammals to be controlled by GH, IGF-I appears to be one of the most specific. Recently, presence of IGF-I was demonstrated in teleosts (see the review of Bern et al. 1991).

The aim of this study was to develop an assay to measure blood levels of IGF-like in rainbow trout (Oncorhynchus mykiss), using the IGF binding pro- 
tein which is present in the blood of this species (Niu and Le Bail 1993). With this binding protein assay, we also investigated the relationship between blood GH and IGF-like levels in the rainbow trout.

\section{Material and methods}

\section{Chemicals}

Recombinant human insulin-like growth factor I (hIGF-I) and II (hIGF-II) were a gift from CibaGeigy (Switzerland). Porcine insulin (I-3503), bovine serum albumin (BSA A-8531) were purchased from Sigma. Bonito insulin, recombinant trout (rtGH), bovine (rbGH) and human (rhGH) growth hormone were kindly provided by Kodama Laboratory (LTD Japan), Eurogentec (Belgium), Mosanto (USA) and Sanofi (France) respectively. Purified pituitary hormones from mammals (oFSH, hGH, bGH, oGH) were supplied by the National Institute of Arthritis and Metabolic Diseases, NIH (Bethesda, Md). ${ }^{125}$ I-hIGF-I was prepared using the method previously described for ${ }^{125}$ I-sGH (Le Bail et al. 1991). The specific radioactivity $(\mathrm{SA}=$ radioactivity content/protein content) varied between 80 to $160 \mu \mathrm{Ci} / \mu \mathrm{g}$. Labelled hormone was stored at $-20^{\circ} \mathrm{C}$ in glycerol $(\mathrm{v} / 2 \mathrm{v})$.

\section{Biological materials}

Human serum was a gift from the Blood Transfusion Center (Rennes, France). Bovine serum was purchased from a local slaughter house. Rainbow trout, tilapia (Oreochromis niloticus) and carp (Cyprinus carpio) plasma was prepared from fish raised in our hatchery in Rennes. After anesthesia (1:3000 phenoxyethanol), blood samples were taken from the caudal vessel of each fish with a heparinized syringe. Plasma was immediately separated by centrifugation at $2000 \times \mathrm{g}$ for $15 \mathrm{~min}$ at $4^{\circ} \mathrm{C}$ and the supernatants frozen at $-20^{\circ} \mathrm{C}$ until extraction. Rainbow trout tissues (ovary, pancreas, brain, liver, kidney and muscle) were minced and homogenized in $50 \mathrm{mM}$ Tris buffer ( $\mathrm{pH} \mathrm{7.5)} \mathrm{using}$ a Polytron tissue grinder. The homogenates were centrifuged $(3000 \times \mathrm{g}, 30 \mathrm{~min})$ and the supernatants frozen at $-20^{\circ} \mathrm{C}$ until extraction. Preparation of the binding protein (BP) used in the assay was carried out according to Niu and Le Bail (1993).

\section{IGF extraction method}

IGF from plasma or tissue homogenates was extracted to eliminate IGF-BP using C-25 Sephadex method summarized in Fig. 1. At the end of the procedure, sample extract dilution corresponded to $1: 10$. Recovery of ${ }^{125}$ I-hIGF-I preincubated $(20 \mathrm{~h}$, $\left.4^{\circ} \mathrm{C}\right)$ with plasma was $90 \pm 3.1 \%(n=21)$. Contamination by IGF-BP was estimated using BP assay and western-ligand-blots. After extraction by the C-25 Sephadex method, plasma was desalted and concentrated with a Centricon-10 (Millipore) until the initial plasma volume was reached. Nonextracted plasma from the same batch was used as control. The extracts were then chromatographed on an AcA54 column using acid buffer (Binoux et al. 1984) and the BP activity of the void volume was measured as described below. Western-ligand-blots were performed according to Hossenlopp et al. (1986), as described in Niu and Le Bail (1993).

For the recovery experiment, free IGF extract was obtained after two incubations $\left(2 \mathrm{~h}, 4^{\circ} \mathrm{C}\right)$ of 10 $\mathrm{ml}$ plasma IGF extract with $10 \mathrm{ml}$ suspended charcoal prepared as described in IGF binding protein assay procedure.

\section{IGF binding protein assay (BPA) procedure and $G H$ radioimmunoassay}

The IGF binding assay was performed using a protocol similar to that described by Binoux et al. (1984). Fifty $\mu 1$ of ${ }^{125}$ I-hIGF-I $(20,000 \mathrm{cpm})$ in TrisHCI buffer (50 mM Tris, $1 \%$ BSA, pH 7.6) were incubated $\left(24 \mathrm{~h}, 4^{\circ} \mathrm{C}\right)$ with $100 \mu \mathrm{l}$ of BP preparation (to obtain $25 \% \mathrm{Bo} / \mathrm{T}$ ) and with $350 \mu$ l of sample extract or standard hIGF (in $200 \mathrm{mM}$ Tris, $1 \%$ BSA, $\mathrm{pH}=9$ ). At the end of incubation, $0.5 \mathrm{ml}$ of suspended charcoal $(5 \% \mathrm{w} / \mathrm{v}$ of charcoal in $50 \mathrm{mM}$ Tris-HCI pH 9 preincubated $4 \mathrm{~h}$ at $4^{\circ} \mathrm{C}$ with $0.5 \%$ 


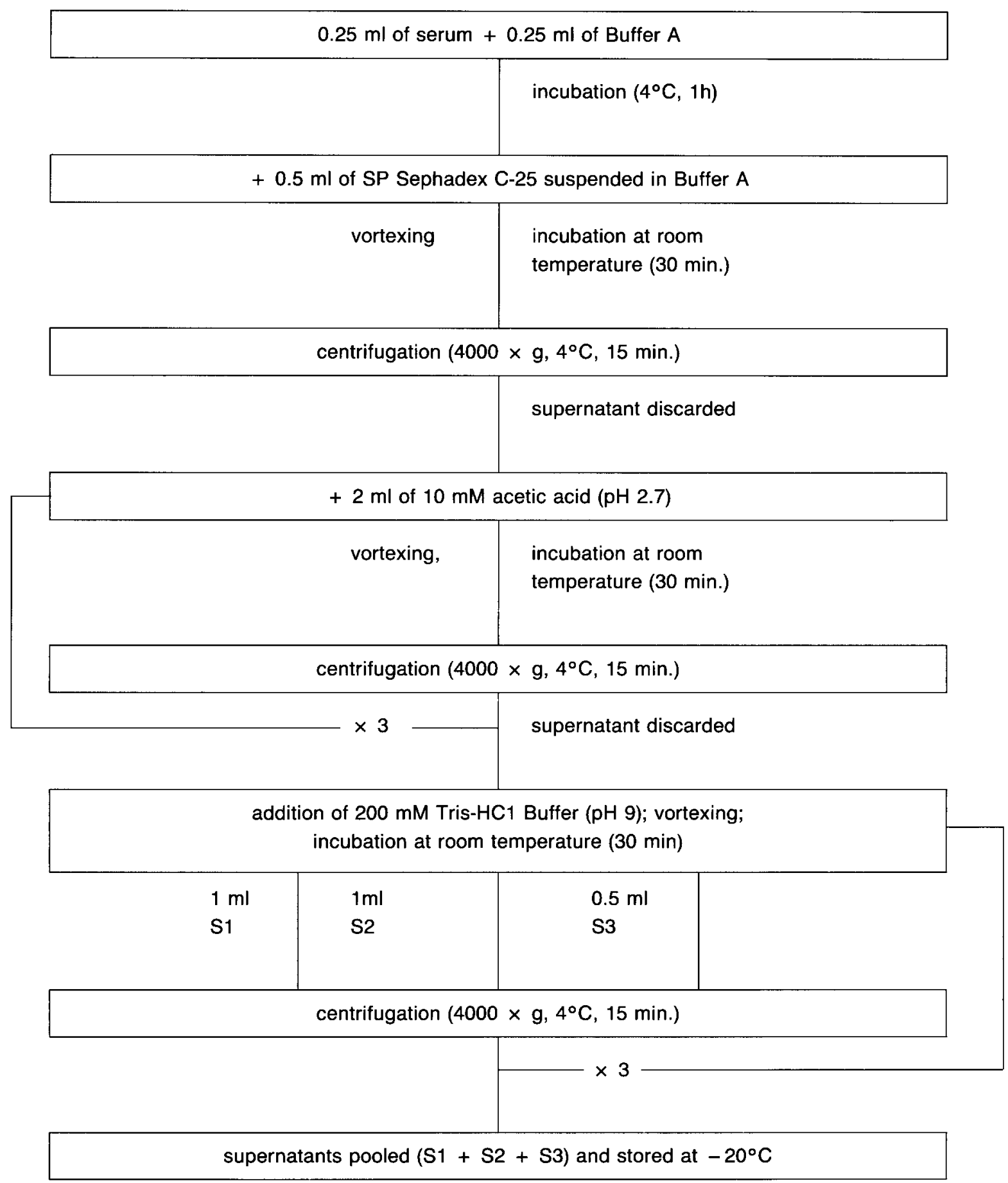

Fig. 1. Diagram of plasma IGF extraction method using Sephadex C-25 as absorbant. Buffer $\mathrm{A}=1 \mathrm{M}$ acetic acid, $0.15 \mathrm{M} \mathrm{NaCl}, \mathrm{pH} 2.7$ 


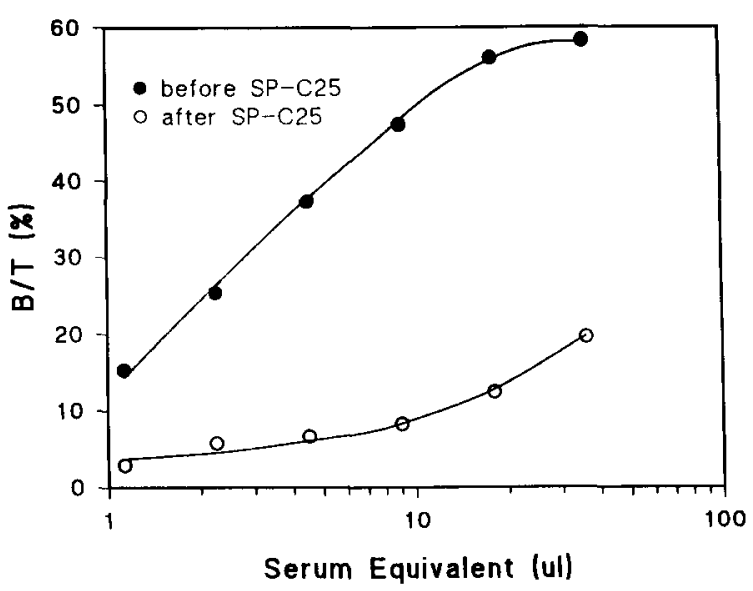

Fig. 2. Residual contamination of trout plasma IGF extract. After extraction by the C-25 method, plasma was desalted and concentrated with a Centricon-10 until initial plasma volume. Extract was chromatographed on an AcA54 column using acid buffer. Binding activity to hIGF-I was measured according to the technique described in Materials and Methods. Non extracted plasma from the same batch was used as control. Binding is expressed as a percentage of total radioactivity added.

BSA) was added to separate bound and free ${ }^{125} \mathrm{I}$ hIGF-I. After $75 \mathrm{~min}$ at $4^{\circ} \mathrm{C}$, tubes were centrifuged $(4,000 \times \mathrm{g}, 15 \mathrm{~min})$ and the charcoal pellets (free IGF) were counted in an automatic gamma counter (Packard Multi-Prias 2). Parallelism of inhibition curves from the IGF-BP assay was tested using Fisher's test after $\log / \operatorname{logit}$ transformation.

GH radioimmunoassay was performed according to the technique described by Le Bail et al. (1991).

\section{In vivo experiments}

Daily profile of plasma GH and IGF-like in juvenile rainbow trout

Rainbow trout $(1+; 100 \mathrm{~g}$ body weight) were maintained 2 weeks before experimentation in $1 \times 0.5$ $\times 0.3 \mathrm{~m}$ tanks (10 fish/tank) under natural photoperiod at $12^{\circ} \mathrm{C}$. Fish were fed ad libitum until the beginning of the experiment but were not fed during the experiment. Every $1.5 \mathrm{~h}$, all the fish in one tank were killed in concentrated anaesthetic (1:300 phenoxyethanol) and blood was obtained in less than $5 \mathrm{~min}$. Fisher test was used to analyse the significance of the correlation between GH and IGFlike levels.

Daily profile of plasma GH and IGF-like in cannulated adult rainbow trout

Two year old mature rainbow trout (1 to $1.5 \mathrm{~kg}$ ) were maintained in individuals tanks $(1 \times 0.5 \times$ $0.3 \mathrm{~m}$ ) under natural photoperiod at $12^{\circ} \mathrm{C}$ and fed ad libitum for three weeks before experimentation. Animals were cannulated according to the technique of Zohar (1980) and allowed to recover for five days. The fish were not fed on the day of the experiment and blood $(200 \mu \mathrm{l})$ was obtained each hour.

bGH treatment and starvation experiment Rainbow trout $(1+; 140 \mathrm{~g})$ were maintained 2 weeks before experimentation in $1 \times 1 \times 0.3 \mathrm{~m}$ tanks under natural photoperiod (October) at $15^{\circ} \mathrm{C}$, then they were divided in 3 groups ( 8 or 9 fish per group). The first group was injected twice weekly with $100 \mu \mathrm{l}$ of $0.9 \% \mathrm{NaCl}$ containing bGH (1 $\mu \mathrm{g} / \mathrm{g}$ of body weight); a second group received only $0.9 \% \mathrm{NaCl}$. Both groups were fed ad libitum during the 4 weeks of the experiment. The third group was starved and injected twice weekly with $100 \mu \mathrm{l}$ of $0.9 \% \mathrm{NaCl}$ during the same period. Blood was obtained $30 \mathrm{~h}$ after the last injection from fish killed in concentrated anaesthetic. Comparison of plasma hormone levels between the various groups, was made using the Wilcoxon-Mann-Whitney test.

\section{Results}

\section{IGF extract contamination by binding protein}

Fig. 2 shows residual binding activity of IGF in plasma extracted by the C-25 method compared to the same unextracted plasma. Significant binding activity was observed only with a concentration of plasma extract higher than $10 \mu \mathrm{l}$. Similar binding activity was obtained with 16 -fold lower concentration of unextracted plasma and corresponded to a a residual binding activity of $6.3 \pm 2.6 \%(n=3)$. With $10 \mu$, which was the concentration of plasma 


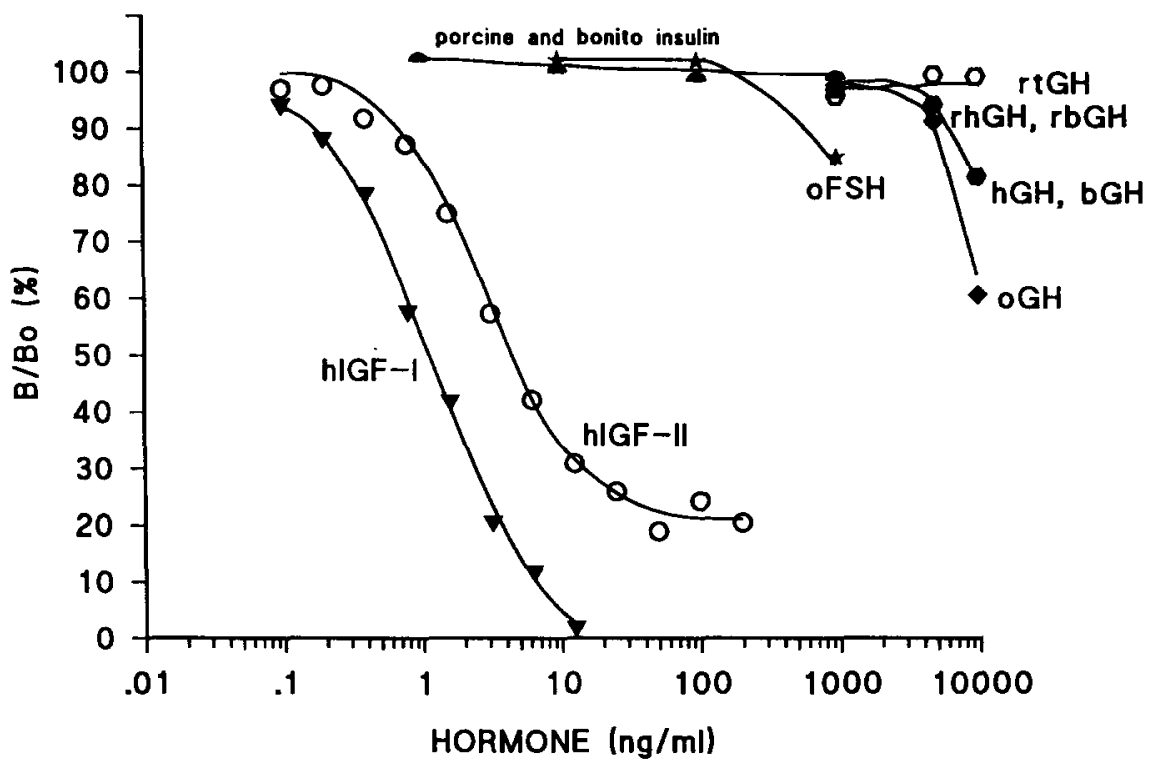

Fig. 3. Competitive inhibition curves for specific binding of ${ }^{125}$ I-hIGF-I to trout plasma binding preparation (tBP) by increasing concentration of vertebrate hormones. $r$ (recombinant), h (human), b (bovine), o (ovine), $t$ (trout), IGF (insulin-like growth factor), GH (growth hormone), FSH (follicle stimulating hormone). Each point is the mean of duplicate determinations.

extract used in the IGF protein binding assay, no significant binding was observed.

\section{IGF BPA characterization}

When incubation was carried out with a fixed concentration of labeled hIGF-I and IGF-BP preparation, specific binding could be competitively inhibited by increasing concentrations of unlabelled hIGF-I (Fig. 3). The concentration of cold hIGF-I required to obtained $90 \%$ and $50 \%$ displacement of the tracer was about $0.15-0.4$ and $1-3 \mathrm{ng} / \mathrm{ml}$ respectively. The inhibition curve for hIGF-II was partial and unparallel to the hIGF-I curve, and 50\% displacement was obtained with a concentration 2-fold higher.

Porcine and bonito insulin and recombinant trout, bovine and human $\mathrm{GH}$ had no significant effect on binding. Purified mammalian pituitary hormones (oFSH, hGH, bGH, oGH) caused significant displacement only at concentrations higher than $1 \mu \mathrm{g} / \mathrm{ml}$.

Repeated determinations of the IGF-like concentration of a single rainbow trout plasma extract gave an intra- $(\mathrm{n}=10,2.4 \mathrm{ng} / \mathrm{ml})$ and inter- $(\mathrm{n}=$ $5,0.92 \mathrm{ng} / \mathrm{ml}$ ) assay coefficients of variation of $13.3 \%$ and $15.7 \%$ respectively. Recovery experiments, conducted by measuring increasing concentrations of hIGF-I $(0.2$ to $50 \mathrm{ng} / \mathrm{ml})$ added into 100 $\mu$ l plasma extract free of IGF-like, produced regression slope equivalent to 1 .

All the serial dilutions of plasma extracts from different vertebrate species tested produced displacement curves not significantly different from that of the hIGF-I standard curve (Fig. 4). Carp plasma extract contained IGF-like activity similar to that of human and bovine serum extract. Rainbow trout and tilapia plasmd extract had a much lower and much higher activity than the mammalian serum extracts, respectively.

\section{IGF tissue concentration}

The IGF-like activity in extracts from different tissues of rainbow trout was examined (data not shown). As above, plasma extract produced an inhibition curve parallel to the standard curve with IGF-like activity which corresponded to $300 \mathrm{ng} / \mathrm{ml}$. 


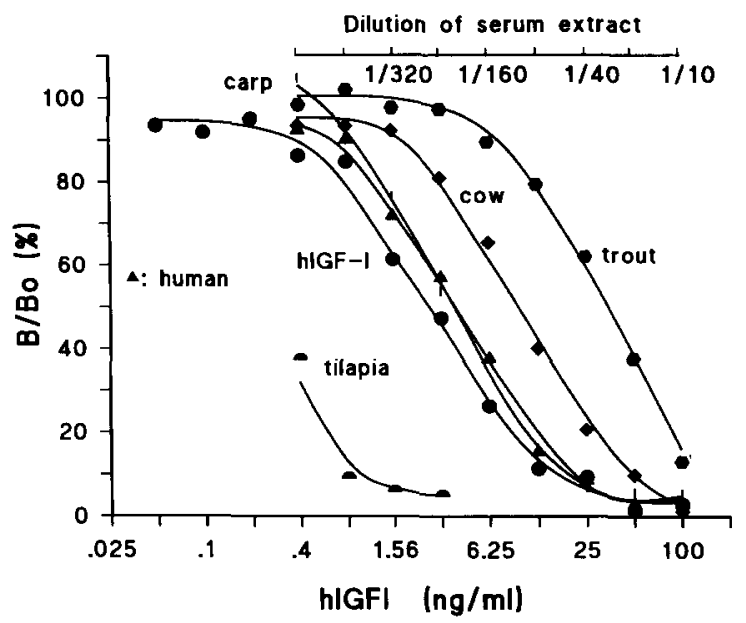

Fig. 4. Competitive inhibition curves for specific binding of ${ }^{125}$ I-hIGF-I to trout plasma binding protein preparation (tBP) by increasing concentration of plasma extract from vertebrate species. hIGF-I was used as standard. Each point is the mean of duplicate determinations. Maximum specific binding corresponds to $30 \%$ of the total ${ }^{125}$ I-IGF-I added (Bo/T).

It was not possible to compare slopes from tissue extracts because their IGF-like concentration seems to be very low $(<4 \mathrm{ng} / \mathrm{ml}$ ). If we take into account the protein concentration of the extracts, IGF-like activity in plasma appeared to be at least 100 -fold higher than in other tissues (data not shown).

\section{GH and IGF relationship}

Using groups of 10 animals killed every 1.5 hour, the daily plasma profiles of juvenile $(1+)$ rainbow trout was studied (Fig. 5). Fluctuations of GH and IGF-like levels were observed which suggest that a synchronous secretion of these two hormones exists between animals. The range of variation of $\mathrm{GH}$ and IGF-like levels were $0.2-2 \mathrm{ng} / \mathrm{ml}$ and $40-70 \mathrm{ng} / \mathrm{ml}$ respectively. The correlation between $\mathrm{GH}$ levels and IGF-like levels with a 1.5 hour delay is significant $(\mathrm{r}=0.58, \mathrm{p}<0.05, \mathrm{~N}=14)$.

When studying individual daily profiles of plasma GH and IGF-like from catheterized adult $(2+)$ rainbow trout sampled every hour (Fig. 6), fluctuations of GH and IGF-like levels were also observed; their range of magnitude and their delay (1-3 hours) varied between animals. The relationship be-

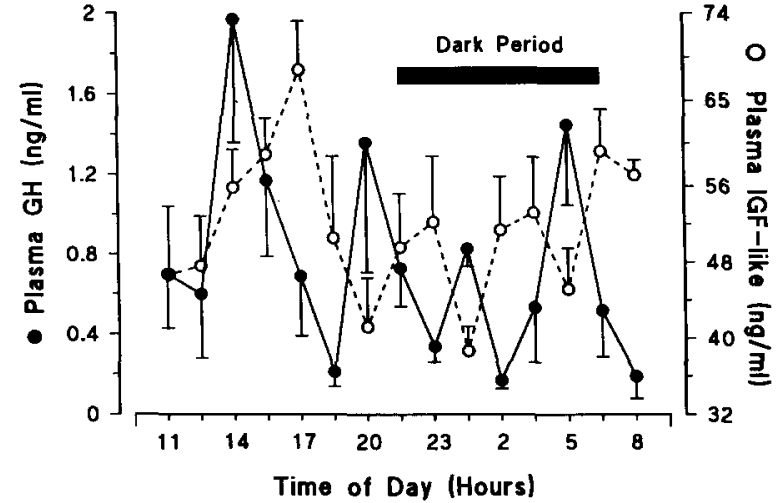

Fig. 5. Daily profiles of plasma GH and IGF levels from juvenile $(1+)$ rainbow trout. Every 1.5 hour, fish were killed and sampled. Mean and standard deviation were calculated from ten values. The dark horizontal bar corresponds to the scotophase, which was preceded and followed by a 30 -min slow increase or decrease of light, respectively.

tween GH levels and IFG-like levels, which occurred one hour later, appeared very different from one fish to another (Fig. 7) since for a similar level of $\mathrm{GH}$, the corresponding IGF-like levels could vary from one to three times.

Fig. 8 shows the effects of starvation and bovine GH on IGF-like plasma levels in rainbow trout. The decrease in body weight shows the effectiveness of four weeks of starvation. In these animals, plasma GH levels significantly increased in parallel with a decrease in plasma IGF-like levels. Conversely, injections of bGH during four weeks dramatically increased body weight as well as plasma IGF-like levels. No significant difference was observed in endogenous plasma GH levels between GH-treated and control fish.

\section{Discussion}

To prevent interference by IGF-BP in any IGF assay, all samples have to be submitted to a preliminary extraction step to discard IGF-BP (Clemmons and Van Wyk 1984; Humbel 1990). In fish, techniques previously used to extract samples include gel filtration chromatography at acidic $\mathrm{pH}$ (Wilson and Hintz 1982; Daughaday et al. 1985; Drakenberg et al. 1989) and reverse phase chromatography 


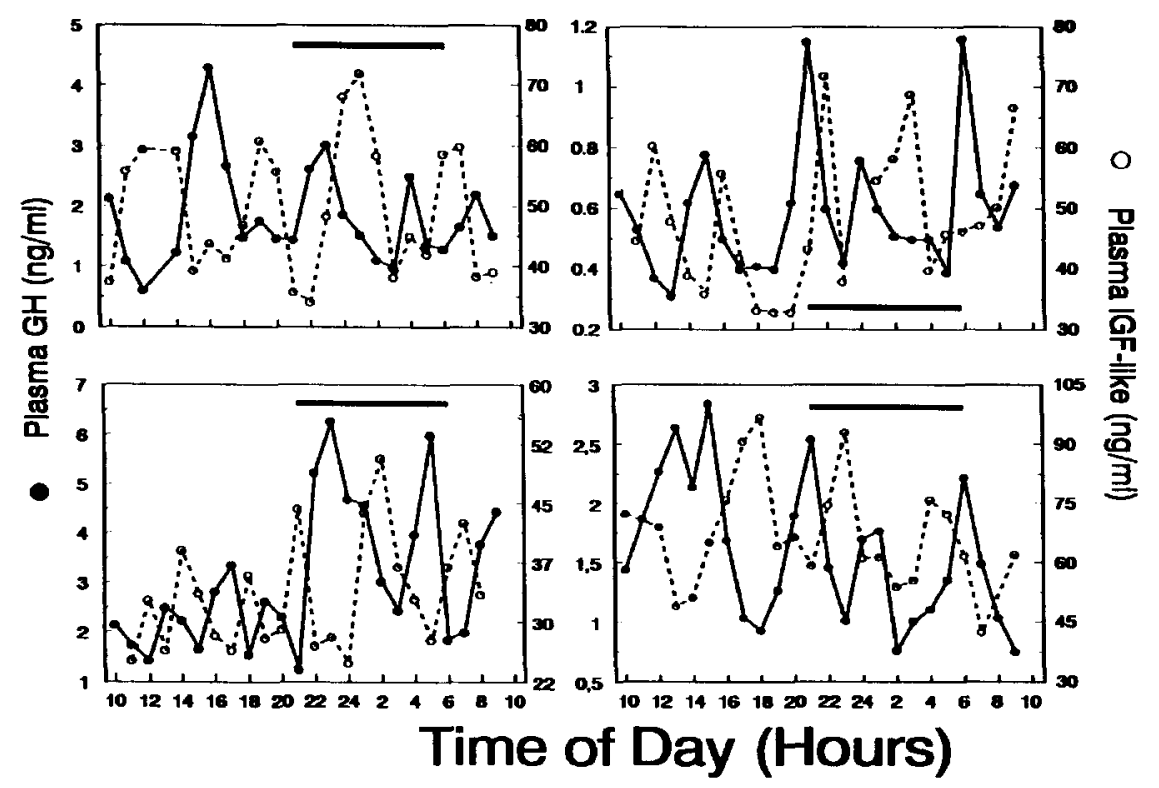

Fig. 6. Individual daily profiles of plasma GH and IGF levels from four catheterized adulte ( $2+$ ) rainbow trout. Three hundred $\mu 1$ of blood were sampled every hour for GH and IGF determination. The dark horizontal bars correspond to the scotophase, which was preceded and followed by a $30 \mathrm{~min}$ slow increase or decrease of light, respectively.

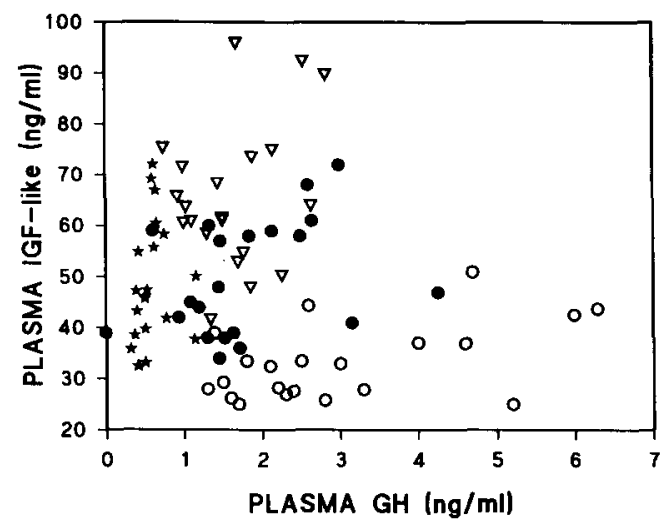

Fig. 7. Correlation between plasma GH and IGF levels in cannulated adult rainbow trout. Each point was plotted using GH levels and IGF levels (occurring one hour latter) from the experiment presented in Fig. 6. Each symbol corresponds to one trout.

(Funkenstein et al. 1989; Ng et al. 1991). However, these techniques are time-consuming, making it difficult to efficiently process a large number of samples. We designed a simpler methodology which takes into account the affinity of IGF at acidic $\mathrm{pH}$ for ionic exchange matrix (Martin and Baxter 1986; Baxter et al. 1989). Our technique presents three advantages: it allows many samples to be as- sayed in a minimum of time, does not modify the binding affinity of IGF and allows for a high recovery of IGF in plasma $(90 \pm 3.1 \%)$. Furthermore, IGF-BP contamination of the extract is low (around 5\%) and has no effect on the assay since the standard curve is not modified by the addition of IGF-BP preparation containing a binding activity similar to the residual contamination (data not shown).

The IGF binding assay described in the present study is an adaptation of a technique classically used in mammals (Binoux et al. 1984) and uses rainbow trout IGF-BP and incubation conditions described elsewhere (Niu and Le Bail 1993). The hormonal specificity is high as insulin which has a structure similar to IGF does not cross react. Purified mammalian pituitary hormones show a very low cross-reaction, although similar recombinant hormones have no effect. It may be that the mammalian purified pituitary hormones are slightly contaminated $(<0.03 \%)$ by IGF. As in mammals (Binoux et al. 1984; Martin and Baxter 1986) the trout IGF-BP assay is not able to distinguish between hIGF-I and hIGF-II and has to be used as an IGF-like assay. Plasma from all species tested 


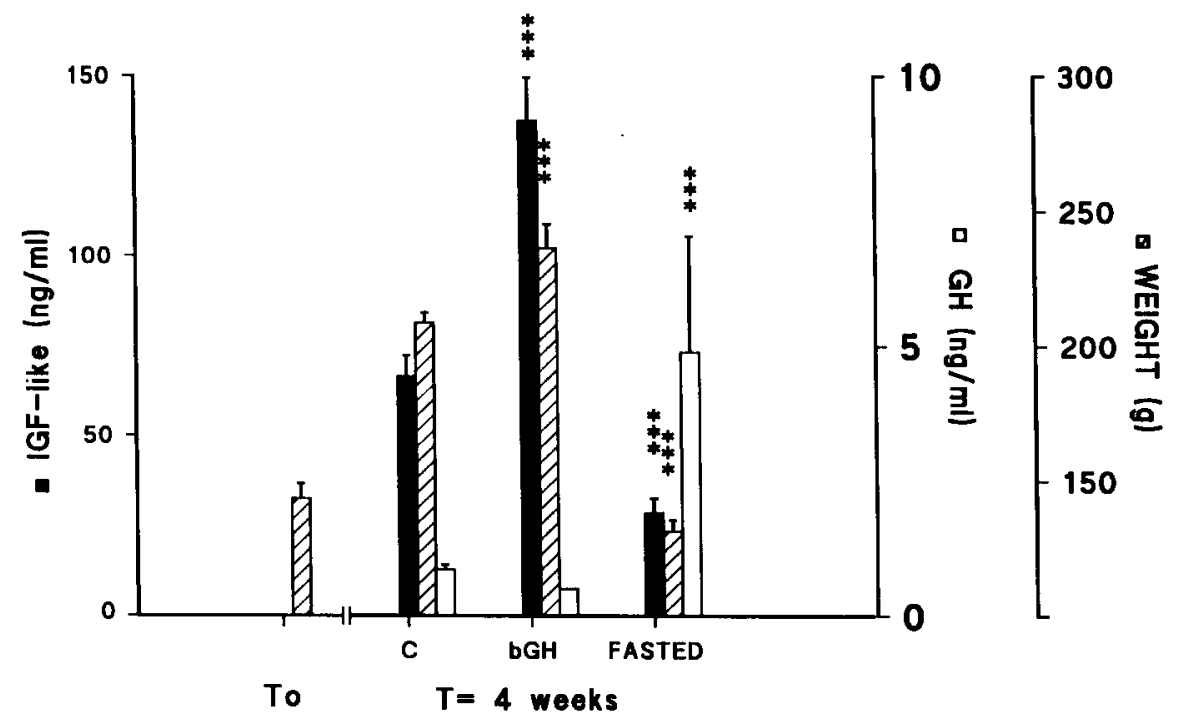

Fig. 8. Effects of bovine GH (bGH) injections and starvation on endogenous $\mathrm{GH}$ and IGF plasma levels of juvenile $(1+)$ rainbow trout. bGH was injected twice weekly at a dose of $1 \mu \mathrm{g} / \mathrm{g}$ of body weight. bGH treatment and starvation took place for four weeks. Each bar corresponds to the mean $\pm \mathrm{SD}$ for eight or nine fish.

produced inhibition curves parallel to the hIGF-I standard curve which suggests that the binding sites of IGF are well conserved during vertebrate evolution.

The present IGF binding assay has relatively high intra- and inter- assay variabilities $(13.3 \%, 15.7 \%)$, which could be due to the charcoal technique used to separate bound and free labeled hIGF-I which induced variability higher than those obtained with second antibody or PEG precipitation. On the other hand, sensitivity is higher than that of the radioreceptor assay (Read et al. 1986) previously used to measure IGF-like in Atlantic salmon (Lindalh et al. 1985) and in tilapia (Drakenberg et al. 1989). Mammalian radioimmunoassays (RIAs), which have a better sensitivity were also used to detect IGF-I in teleost plasma. However, IGF-like activity was not always detected in these RIAs (Furlanetto et al. 1977; Wilson and Hintz 1982; Lindalh et al. 1985; Le Bail unpublished data) and when it is (Daughaday et al. 1985; Funkenstein et al. 1989; $\mathrm{Ng}$ et al. 1991), IGF-like plasma concentrations appear to be one or two orders of magnitude lower than those measured by radioreceptor or binding protein assays. This difference may be due to a lower affinity of mammalian IGF-I antibody for fish IGF-I which was only $80 \%$ homology with mammalian IGF-I (Cao et al. 1989).

The relationship between GH and IGF-I is well established in mammals (Clemmons and Van Wyk 1984; Humbel 1990) and some data support that it also exists in teleosts (Bern et al. 1991; Duan et al. 1993). Our experiments with juvenile and adult rainbow trout provide evidence of a pulsatile IGFlike secretion which depends on the plasma GH level. The delay of induced IGF-like response which occurred 1 to $3 \mathrm{~h}$ after the $\mathrm{GH}$ peak is similar to that in rat (Baxter 1986), but is 10 fold shorter than in human in which an obvious relationship between serum GH and IGF-I concentrations is not observed (Clemmons and Van Wyk 1984). However, a significant correlation between plasma $\mathrm{GH}$ levels and the delayed IGF-like peaks is not always found, particularly in some cannulated rainbow trouts. This could be explained by an unadapted serial sampling and by a nyctemeral variation in the delay of IGF-like secretion in response to GH. The amplitude of this response also shows individual variations as was observed in the canulated trout experiment.

Sensitivity to GH treatment in fish depends on numerous factors (Le Bail et al. 1992) in which 
nutritional status has an important role. In mammals, resistance to GH secretion and plasma IGF-I concentration appear to be tightly controlled by dietary intake (Clemmons and Van Wyk 1984). The results obtained in the starvation experiment (increase in GH and decrease in IGF-like levels) suggest that a similar regulation exists in trout. These data are in accord with the IGF-I mRNA decrease observed in the liver of starved eel (Duan and Hirano 1992). On the other hand, starvation would not have effect on the cartilage receptivness to IGFI as it was observed in coho salmon (McKormick et al. 1992). In tilapia, Drakenberg and coworkers (1989) were unable to establish a similar relationship. It may be that the starvation period ( 9 days) to which they submitted their tilapia was too short. At least 3 weeks of starvation appear to be necessary to induce a significant decrease of plasma IGF levels (Yao and Le Bail, unpublished data; PérezSanchez et al. 1992).

Recently, in rainbow trout liver, Shamblott and Chen (1992) have identify an IGF mRNA which could correspond to the mammalian IGF-II. However, IGF-II-like activity, assayed by rat radioreceptor assay, was not detected in teleost plasma (Daughaday et al. 1985; Drakenberg et al. 1989). All the results obtained in the present work, plasma GH/IGF-like correlation, GH induced increase of plasma IGF-like and plasma IGF-like decrease by starvation, suggest that the trout IGF-like factor variations, measured by our binding protein assay, corresponds to IGF-I which would then be the major IGF form present in trout plasma as was claimed by Daughaday et al. (1985).

\section{Acknowledgements}

We thank Dr Swift from Ciba-Geigy, Dr Smal from Eurogentec and the NIH for providing hIGFs, $\mathrm{rtGH}$ and purified pituitary hormones respectively. We are grateful to Dr M. Binoux and Dr. S. Hardouin, INSERM U.142, Paris, for helpful discussion. This work was mainly supported by grant from the "Region Bretagne" and the French National Institute of Agronomical Research (INRA).

\section{References cited}

Baxter, R.C. 1986. The somatomedins: insulin-like growth factors. Adv. Clin. Chem. 25: 49-115.

Baxter, R.C. and Martin, J.L. 1989. Binding proteins for the insulin-like growth factors: structure, regulation and function. Progress in Growth Factor Research 1: 49-68.

Bern, H.A., McCormick, S.D., Kelley, K.M., Gray, E.S., Nishioka, R.S., Madsen, S.S. and Tsai, P.I. 1991. Insulinlike growth factors "under water": role in growth and function of fish and other poikilothermic vertebrates. In Modern Concepts of Insulin-Like Growth factors. pp. 85-96. Edited by E.M. Spencer. Elsevier, New York.

Binoux, M., Seurin, D., Lassarre, C. and Gourmelen, M. 1984. Preferential measurement of insulin-like growth factor (IGF) I-related peptides in serum with the aid of IGF-binding proteins (IGF-BPs) produced by rat liver in culture. Estimation of serum IGF-BP levels. J. Clin. Endocrinol. Metab. 59: 453-462.

Cao, Q.P., Duguay, S.J., Plisetskaya, E., Steiner, D.F. and Chan, S.J. 1989. Nucleotide sequence and growth hormone regulated expression of salmon insulin-like growth factor I mRNA. Mol. Endocrinology 3: 2005-2010.

Clemmons, D.R. and Van Wyk, J.J. 1984. Factors controlling blood concentration of somatomedin C. Clin. Endocrinol. Metab. 13: 113-143.

Daughaday, W.H., Kapadia, M., Yanow, C.E., Fabrick, K. and Mariz, I.K. 1985. Insulin-like growth factors I and II of nonmammalian sera. Gen. Comp. Endocrinol. 59: 316-328.

Drakenberg, K., Sara, V.R., Lindahl, K.I. and Kewish, B. 1989. The study of insulin-growth factors in tilapia, Oreochromis mossambicus. Gen. Comp. Endocrinol. 4: 173-183.

Duan, C. and Hirano, T. 1992. Effects of insulin-like growth factor-I and insulin on the in-vitro uptake of sulfate by eel branchial cartilage: evidence for the presence of independent hepatic and pancreatic sulphation factors. 133: 211-219.

Duan, C., Duguay, S.J. and Plisetskaya, E.M. 1993. Insulinlike growth factor I (IGF-I) mRNA expression in coho salmon, Oncorhynchus kisutch: tissue distribution and effects of growth hormone/prolactin family proteins. Fish Physiol. Biochem. This issue.

Fryer, J.N. and Bern, H.A. 1979. Growth hormone binding to tissues of normal and stunted juvenile coho salmon Oncorrhunchus kisutch. J. Fish Biol. 15: 527-533.

Funkenstein, B., Silbergeld, A., Cavari, B. and Laron, Z. 1989. Growth hormone increases plasma levels of insulin-like growth factor (IGF-I) in a teleost, the gilthead seabream (Sparus aurata). J. Endocrinol. 120: R19-R21.

Furlanetto, R.W., Underwood, L.E., Van Wyk, J.J. and D'Ercole A.J. 1977. Estimation of somatomedin-C levels in normals and patients with pituitary disease by radioimmunoassay. J. Clin. Invest. 60: 648-657.

Gray, E.S., Young, G.G. and Bern, H.A. 1990. Radioreceptor assay for growth hormone in coho salmon (Oncorhynchus kisutch) and its application to the study of stunting. J. Exp. Zool. 256: 290-296. 
Hossenlopp, P., Seurin, D., Segovia-Quinson, B., Hardouin, S. and Binoux, M. 1986. Analysis of serum insulin-like growth factor binding proteins using western blotting: use of the method for titration of the binding proteins and competitive binding studies. Anal. Biochem. 154: 138-143.

Humbel, R.E. 1990. Insulin-like growth factors I and II. Eur. J. Biochem. 190: 445-462.

Le Bail, P.-Y., Pérez-Sanchez, J., Yao, K. and Maisse, G. 1993. Effect of GH treatment on salmonid growth: study of the variability of response. Est. Cost. Stud. (In press).

La Bail, P.-Y., Sumpter, J.P., Carragher, J., Mourot, B., Niu, P.D. and Weil, C. 1991. Development and validation of high sensitive radioimmunoassay to chinook salmon (Oncorhynchus tshawytscha) growth hormone. Gen. Comp. Endocrinol. 83: $75-85$.

Le Gac, F., Ollitrault, M., Loir, M. and Le Bail, P.-Y. 1992. Evidence for binding and action of growth hormone $(\mathrm{GH})$ in trout testis. Biol. Reprod. 46, 949-957.

Lindahl, K.I., Sara, V., Fridberg, G. and Nishimiya, T. 1985. The presence of somatomedin in the baltic salmon, Salmo salar, with special reference to smoltification. Aquaculture 45: 177-183.

Martin, J.L. and Baxter, R. 1986. Insulin-like growth factorbinding protein from human plasma, purification and characterization. J. Biol. Chem. 261: 8754-8760.

Maiter, D., Maes, M., Underwood, L.E., Fliesen, T., Gerard, G. and Ketelslegers, J.-M. 1988. Early changes in serum concentrations of somatomedin- $\mathrm{C}$ induced by dietary protein deprivation in rats: contributions of growth hormone receptor and post-receptor effects. J. Endocrinol. 118: 113-120.

McCormick, S.D., Tsai, P.I., Kelley, K.M., Nishioka, R.S. and Bern, H.A. 1992. Hormonal control of sulfate uptake by branchial cartilage of coho salmon: role of IGF-I. J. Exp. Zool. 262: 166-171.

Ng, T.B., Leung, T.C. and Woo, N.Y.S. 1991. Insulin-like growth factor-I like immunoreactivity in the serum and tissues of the tilapia, Oreochromis mossambicus. Biochem.
Inter. 24: 359-368.

Niu, P.-D, and Le Bail, P.-Y. 1993. Presence of insulin-like growth factor binding protein (IGF-BP) in rainbow trout (Oncorhynchus mykiss) plasma. J. Exp. Zool. (In press).

Pérez-Sanchez, J., Smal, J. and Le Bail, P.-Y. 1991. Location and characterization of growth hormone binding sites in the central nervous system of a teleost fish (Oncorhynchus mykiss).Growth Reg. 1: 145-152.

Read, L.C., Ballard, F.J., Francis, G.L., Baxter, R.C., Bagley, C.J. and Wallace, J.C. 1986. Comparative binding of bovin, human and rat insulin-like growth factor to membrane recepteurs and to antibodies against human insulin-like growth factor-1. Biochem. J. 233: 215-221.

Sakamoto, T. and Hirano, T. 1991. Growth hormone receptors in the liver and osmoregulatory organs of rainbow trout: characterization and dynamics during adaptation to sea water. J. Endocrinol. 130: 425-433.

Shamblott, M.J., Chen, T.T. 1992. Identification of a second insulin-like growth factor in a fish species. Proc. Nat. Acad. Sci, U.S.A. 89: 8913-8917.

Thissen, J.P., Triest, S., Underwood, L.E. and Ketelslegers, J.M. 1990. The decreased plasma concentration of insulinlike growth factor-I in protein-restrited rats is not due to decreased numbers of growth hormone receptors on isolated hepatocytes. J. Endocrinol. 124: 159-165.

Wilson, D.M. and Hintz, R.L. 1982. Inter-species comparison of somatomedin structure using immunological probes. J. Endocrinol. 95: 59-64.

Yao, K., Niu, P.D., Le Gac, F. and Le Bail, P.-Y. 1991. Presence of specific growth hormone binding sites in rainbow trout (Oncorhynchus mykiss) tissues: characterization of the hepatic receptor. Gen. Comp. Endocrinol. 81: 72-82.

Zohar, Y. 1980. Dorsal aorta catheterization in rainbow trout (Salmo gairdneri). I. Its validity in the study of blood gonadotropin patterns. Reprod. Nutr. Develop. 20: 18111823. 